\title{
Poetics of Audiovisual Translation: the Barber of Siberia on French Screen
}

\author{
Vera E. Gorshkova* \\ Irkutsk State University \\ 8 Lenin Str., Irkutsk, 664025, Russia
}

Received 10.01.2017, received in revised form 17.10.2017, accepted 30.10.2017

A comprehensive review of poetics from view points of literary studies, cinematography and translation allows the author of the paper to derive a notion of audiovisual translation poetics. It is stated that while translating a film one has to consider a subjective poetic vision of the film director that determines the genre of the cinema of poetry in terms by P.P. Pasolini and J. Genevray. The author's speculations are illustrated by a case study of the Barber of Siberia, a feature film by Nikita Mikhalkov.

Keywords: poetics, poetic cinema, audiovisual translation.

DOI: 10.17516/1997-1370-0167.

Research area: philology and translatology.

The poetic forms a basis of any spiritual or intellectual activity. Kenneth White, the International Institute of Geopoetics founder

The wording of the declared subject of our article makes it necessary to study the notion of "poetics" from various viewpoints that is to approach it from domains of literary science, cinematography and translation. This algorithm will allow us to define what the poetics of audiovisual translation means and to provide an example of the latter.

\section{Literary approach}

Poetics (from the Greek poietike - the art of poetry) is traditionally represented as a branch of literature studying the system of literary techniques in literary texts and ways they interact creating "an image of the world" and "an image of the author" in these texts. The junction point of subdisciplines of poetics (general, special and historical poetics) lies in the fact that they all approach fine literature from the viewpoint of its specific character and consistently elaborate the poetic art theory in following ways:

1) in accordance with the order of development of scientifically valid aesthetic norms;

2) as a dogmatic declaration of creative principles;

3) as an empirical analysis of the poetic structure;

(c) Siberian Federal University. All rights reserved

* Corresponding author E-mail address: gorchkova_v@mail.ru 
4) by means of reconstructing history of the development of literary forms.

There is a more narrow interpretation of poetics. Thus, the Dictionary of Literary Terms defines poetics as a theory of poetry aimed at establishing the origin, principles and gist of poetry writing. It should be noted that the above interpretation highlights a descriptive rather than normative nature of poetics as it describes "things existent rather than proper, on the basis of facts of poetry itself rather than preliminary speculations"1.

\section{Cinematographic approach}

Although the existence of poetic cinema casts no doubts, a relation of cinema and poetry causes more questions than answers. What is cinema? How to classify it taking into consideration a great variety of media and the bloom of digital technologies? How to understand poetry in the cinematographic context as nowadays there is an unprecedented variety of poetic forms from vers libre to video poems (Gorshkova, 2015: 28)? Can one speak of poetry beyond a written text?

Each of these questions were asked by Pier Paolo Pasolini in his manifesto, the Cinema of Poetry, where the author makes a categorical statement that "the language of cinema is fundamentally a "language of poetry"" (Pasolini, 1985: 49). Why? The scholar considers it necessary to write about the expressive language of cinema backed up by use of semiotic terminology and, correspondingly, differentiates between linguistic signs and image-signs, or, in his own terms, lin- and im-signs.

P.P. Pasolini writes that an instrumental basis of cinematographic communication is found in a complex set of resources which make up the latter. In contrast with the dictionary of linguistic signs a writer has at hand, a dictionary of im-signs does not exist as such thus a film director builds it up from chaos of images around him. While subjectively/spontaneously selecting im-signs the film director is guided by "an ideological and poetic vision of the reality that he has at the moment", in other words he "uses a rather subjective language of im-signs" (Pasolini, 1985: 51).

Thus "cinema or the language of im-signs has a double nature. It is extremely subjective and at the same time extremely objective $\langle\ldots>$. These two essential aspects are closely bound together to the point of being inseparable even for the needs of an analysis. The literary function is also double by nature: but its two faces are discernible: there is a "language of poetry" and a "language of prose" so differentiated that they are diachronic and have two divergent histories" (Pasolini, 1985: 51).

Such understanding of poetics and poetry in cinema determined by a peculiar vision of the filmmaker, the director's approach to representation of events rather than events as they are, is shared by a number of scholars (Genevray, 2014). In this regard it is interesting to mention the experience of Rithy Panh, a FrenchCambodian film director, who could hardly speak French when he started his creative work in France: "There were really few words in my first short films. For example I took a verse by Jacques Prévert and shot "Le Petit Déjeuner": he takes his hat and leaves... Everything is reflected by the visual sequence. In this regard Jacques Prévert is a genius as the interchange of small scenes is so emotionally loaded, they are readymade camera shots! I did not need words. $<\ldots>$ My films were silent because I could not write in French! I was unaware how lucky I was: I had to find the way to express everything by the visuals without the help of a word" (Panh, 2015: 164) (the translation is ours - V.G.).

The account of Rithy Panh shows a strong correlation between understanding of poetics in poetry writing and cinematographic art and 
lays a literal emphasis on "the empirical analysis of poetic structure" by means of the language of cinema. This relation is most explicitly represented when directors use quotes from poetry which is typical of Jean Luc Godard and Federico Fellini who often employed intertextual references to classic Greek and Latin authors and Dante Alighieri (Poirson-Dechonne, 2015), which undoubtedly increased an aesthetic aspect of films of the above directors.

Even though the existence of poetic cinema is recognized, "category features of poetic film and criteria of its quality have not got an established interpretation yet; $<\ldots>$ experts have not arrived at a consensus about poetic film" (Golynko-Volfson, 2012) which accounts for a wide range of approaches to poetic cinema definition $^{2}$. As film critic D. Golynko-Volfson puts it, "a poetic film translates a verbal text (written in a national language and referring to peculiarities of a local environment that are not always clearly understood by the audience) into a globalist language of generally comprehensible visual codes" (Golynko-Volfson, 2012). It is primarily a case of a poetic text screen adaptation, a kind of a hybrid of poetry and cinema where a poetic text is represented by means of interaction of two media, the verbal and the visual, as "a study of what subjectivity of modern man is, how it is created and what ways it manifests itself. In the best examples of poetic film the language of poetry and the language of cinema become mutually problematized or, to put it in Jacques Derrida's terms, they obliterate and strike each other out, in order to create a new discursive statement about subjectivity of modern man, its weakness, improbability and indispensability" (Golynko-Volfson, 2012).

The above mentioned paradigm of subjectivity of modern man correlates, in some way, with the idea of geopoetic cinema that is completely free of essential features of the classic cinema, including music and spoken word ("dialogue explicative" in terminology of A. Gaudin). Poetics of such films is not about representing a poetic work by means of cinema, it is about a way the latter interprets rather than plays out the existential influence of a geophysical environment on the form being shown on the screen which finds its representation in expressive means of cinematography. That "slow cinema" can be exemplified by a feature film by Argentinean director Lisandro Alonso Los Muertos (Argentina, 2004), the story line or "skeletal narrative" of which describes a travel of Vargas, the main character, who goes by boat up the river to see his daughter (Gaudin, 2015). The "action hold-back" strategy, method of "delaying" an event let us open up space and speculate about events, help to behold the present moment and particular details of the physical world. As Theo Angelopoulos says "pauses and dead time give [a viewer] an opportunity not only to evaluate the film rationally but also to create or add various meanings to an episode" 3 .

As Kenneth White, the founder of the International Institute of Geopoetics, writes, "this is neither about a culture "novelty", nor a literary school, nor poetry understood as the innermost and the art. What this means is a movement that touches upon an issue of foundations of a man's existence on the Earth. The key is not to build up a mental system but to complete, step by step, an experiment, your own study, by putting yourself in a particular field emerging at the intersection of poetry, philosophy and science. Geopoetics takes it beginning in creation, movement, current, pace, action, and finds its result in transformative power of art..."4. Consequently, the cinematographic geopoetics allows to deepen and strengthen our relationship with the environment we live in and the planet in general.

Attempts to reconcile cinema and digital (media) poetry that came into being in the 1960s 
opening new ways of poetry writing are also of great interest. According to the experts's opinion, the development of digital and cinematographic technologies makes it possible to create animation poems which, in their form, are the closest to the art of cinema ${ }^{5}$. The transfer from a text to a video sequence and interaction of these two media means encourages a particular rhythm and particular space representation determining a new type of discourse.

Researchers note that digital (media) poetry does not refer to a text illustrated by a video sequence, it is about continuing an interactive dialogue of three media means, i.e. a video sequence, sound and poetic text. In this context changes in meaning introduced by each of these means are studied: sound influences a video sequence, the video sequence is based on a text, and so on. Particular meanings bounce from each other, overlap and create a new poetic object (Kergourlay, 2015). Ernesto Manuel de Melo e Castro, a video poet from Brazil, and Richard Kostelanetz from the U.S. are some of the most prominent representatives of modern video poetry but we cannot help mentioning, along with their names, the name of Tom Konyves, a Canadian video poet. He experiments with video poems the main characters of which are alphabet letters that are spread across the screen and twirl into some patterns, cross the screen as one word that gradually fades away in a particular direction, its syllables changing places at an extremely vivid pulsating background that directly influences the perception of the audience and gives rise to a full range of emotions from true excitement to unconscious, almost uncontrollable aggression which we experienced at the open lecture of the maestro (Konyves, 2015; Gorshkova, 2015).

\section{Translation proper approach}

The above mentioned facts let us conclude that the cinematographic approach to poetics is predetermined first and for most by the nature of a movie as a material medium of the film text and thus it takes our speculations further to the field of genre peculiarities of cinema. As a result the question arises whether is it possible to speak of poetics in regard to every film irrespective of a genre it belongs to or this notion describes a particular genre requiring some particular interpretation and particular research approach?

In order to answer these questions let us go back to the above definition of poetic cinema by P.P. Pasolini that states an ideological and poetic vision of the reality by a film director who uses the language of im-signs that is necessarily subjective to translate the given reality on the screen. So we'll make an attempt to apply these ideas to a translator's work though the case study of Nikita Mikhalkov's feature film the Barber of Siberia and its translations in French by dubbing and subtitling.

In our opinion the film under analysis can be regarded, with good reason, as a poetic cinema example taking into consideration its pronounced aesthetic component that results in the high artistic value of a number of scenes that typify beauty.

It would therefore suffice to mention the scene when cadets of the Emperor's Military School are standing in lines on the parade square waiting for Emperor Alexander III to arrive. The close-up shot gives details of their uniform: golden buttons of their great coats, gilded cap brasses and epaulettes with a red stripe in the middle, glittering shoulder knots; breathless silence interrupted only by gusts of wind... and... a tiny sparrow that is hopping by shinned boots and picking for crumbs, the sparrow that represents a great symbol of a mixture of demonstrated masculinity and fragile pertness so typical of twenty-year-old boys. Or else let us take the scene when embarrassed General Radlov, in a smashing performance of Alexei Petrenko, leaves the house 
of Jane Callahan forgetting to take the clothes hanger out of his great coat. Hardly a word is uttered but what a deep cinematographic message is conveyed! So here they are, the Pasolini's imsigns!

We also consider this feature film as an example of poetic cinema as it completely matches analysis criteria introduced by Jérôme Genevray (Genevray, 2014; Gorshkova, 2016). The main character, Andrei Tolstoi, is childishly ingenuous and is seized by very simple and natural desires. The storyline includes numerous references to the past. The "material" symbol of the film, its sense support is represented by a surrealistic, steam punk machine built by an American adventurer-engineer that is called the Barber of Siberia. We also bear in mind that Andrei, regardless his childish ingenuousness, is a young man with a clearly set life credo (Cf:: The Tolstois stick to their decisions) that is inherited with the father's genes by his son who would go to all lengths to defend his principles (Cf.: Mozart is a great composer!).

"The poetic film $<\ldots>$ means that a poetic utterance should address the mass audience that possesses some intellectual skills but, at the same time, it should be aimed at egalitarian tastes" (Golynko-Volfson, 2012). These words of cinema critic D. Golynko-Volfson surprisingly echo poetic translation definitions in terminology of L. Nelyubin's who states that poetic translation, being a particular type of social communication "people-to-people, heart-to-heart", "should be in line with tastes, education, character and demands of the audience as contrasted with literary translation" (Nelyubin, 2003: 162). They also play with the opinion of audiovisual translation experts: "meaning is not a stable entity, it is a result of the interpretation process carried out within a particular socio-cultural and historical context on the basis of the personal experience of a reader [spectator - V.G.]" (Şerban, 2008: 86).
It is a great pity to say that a number of culturally loaded elements were lost when the Barber of Siberia film dialogue was dubbed into French. It is a common knowledge that the most culturally loaded elements of almost every film refer to the geographic context (Ramière, 2004: 105). It is especially crucial in the context of the target of our analysis as the film is set in different locations, so that the audience is constantly taken from Moscow to the U.S., from the U.S. to Siberia with the help of the montage. From this perspective, the episode when Jane studies the map to find the place where Andrei settles after he served his penal sentence looks funny. The name of the village of Ovsyanka situated in "three kilometers" from Kansk (which is already wrong from the view point of inhabitants of that region) is dubbed as situated near Kan (!). This fact can cause confusion as the city name can be wrongly interpreted by the audience because it is homonymous to Caen, the city in Lower Normandy (France).

The music and song component, the keynote of the film, is also lost in the dubbed version. It is the renowned aria of Figaro that becomes the film leading motive. It is sung first by Andrei Tolstoi at the ninth minute of the film when, by a twist of fate, a tipsy cadet finds himself in Jane Callahan's compartment. When Tolstoi returns to the military school he sings it again to interrupt a marching song of cadets (18:46 - 19:32). The aria is heard when military school students perform the Marriage of Figaro. It also sounds in the affecting scene of seeing off Andrei convicted to a penal service in Siberia when he, squeezed in the railroad car by fellow convicts, tries to let his friends know that his spirit has not been broken by singing the Figaro words. Even though the aria of Figaro is sung in Italian, it belongs to the treasure-house of the world culture and its words are known to every educated person. 
In contrast it cannot be said about the Lord's Prayer that is being read before dinner on the Shrove Sunday when it is heard by Jane Callahan, an American, who secretly comes to the school hospital to visit Tolstoi wounded at the duel with his schoolmate who spoke disrespectfully about the object of Andrei's affections (1:14:30). The Russian anthem God, Save the Tsar! sung by cadets at the day of their graduation from the Emperor's Military School is little known either.

It should be mentioned that in terms of the film's aesthetics (read - poetics!) "song lyrics as a rule perform the double function in a movie, i.e. narrative and aesthetic: the information they carry can attribute to the development of the story line or represent some reflections on the latter.
The form of a song representation (poetical, rhymed, musical) becomes a part of the general aesthetic representation of the cinematographic work, being naturally congruent with the visual and sound patterns of the film or adding some new component to it" (Cornu, 2014: 388-389; Gorshkova, 2016: 250). The marching song of cadets becomes such "new component" that, unfortunately, does not introduce any thoughts as if hanging in the air. It is the same marching song that Andrei tries to interrupt by the Figaro aria in the beginning of the film and it is the song that becomes a hymn to friendship in the scene of seeing Andrei off when his friends, who have lost any hope to find the rail car he is taken by to the penal service in Siberia, began singing it:

\begin{tabular}{|l|l|}
\hline Фуражка, милая, не рвися - & My good ol' cap don’t you get torn - \\
С тобою жизнь моя прошла. & You saw my life pass by. \\
С тобою бурно пронеслися & You witnessed as my wild youth \\
Мои кадетские года. & In the cadet school would fly. \\
$\ldots$ & $\ldots$ \\
Прощайте, черные шинели, & Goodbye, black uniform coats \\
Погоны алого сукна. & And crimson striped epaulettes. \\
Ура! Мы больше не кадеты, & Hurray! We're young junkers now, \\
А молодые юнкера. & We aren't any longer cadets! \\
\hline
\end{tabular}

Generally speaking, this strategy might be chosen to intensify the defamiliarization effect taking into account that the film is represented though the perception of Jane Callahan, an American who does not speak any Russian (a well-known effect of double statement). However, judging from experience, these are songs that present the greatest challenge to an audiovisual translator.

It is worth noting that some of the above mentioned faults were rectified in the subtitled version of the Barber of Siberia. For example, several words of the Lord's prayer (but not the whole text) are given in French subtitles: Dieu, protège le Tsar/notre Tsar tout puissant/règne pour notre gloire/notre gloire à tous (01:28:00).
The line "This film is a homage to Russian military officers - the pride of our Motherland" appearing on the screen before the closing credits is not translated into French which, in our opinion, is an obvious and irreplaceable loss. These words complete the closed-in construction building the bridge to a kind of slogan of the film: "He is Russian. That explains a lot". Thus, intensity of patriotic feelings is lost, the time gets out of joint, sublime poetics is weakened and disappears so that only incomprehensible elision marks are left.

As for the subtitled version the line has been cut out of the film as, evidently, it has no meaning for the French audience. It looks like as if the "no dedication - no problem" rule was followed. But the problem we deal with here is that the 
social and cultural context accounting for the characters' actions in general and admirable stubbornness of Andrei's son about Mozart in particular is of fundamental nature!

The above discussion lets us to conclude that poetics of audiovisual translation is determined by the poetic character of the material medium of a cinematographic message (i.e. the film) the degree of which is intensified in the genre of a poetic cinema that is characterized by a specific way of the verbal component representation, its extreme explicit representation being the poetic form of the film dialogue. As a result, an audiovisual translator should be aware of the filmmaker's subjective poetic vision of the film and, consequently, apply adequate verbal means in accordance with the employed audiovisual translation method.

\footnotetext{
Academic Dictionaries and Encyclopedias. Available at: http://dic.academic.ru/dic.nsf/enc3p/242178

2 See a selection of works of the «CinémaAction» special issue entitled «L'écran poétique» (2015) which directly reflects the subject of our research.

Available at: http://rutracker.org/forum/viewtopic.php?t=2985116

4 Available at: http://www.liter.net/geopoetics/golov.html

5 We do not mean here the digital poetry that is made up of digits linked to each other by the rhyme and rhythm into an integral whole.
}

\section{References}

Finzi, N. (2016). La voix off. Faire de sa voix un métier. Paris: DIXIT. 141 p.

Gambier, Y. (2004). La traduction audiovisuelle : un genre en expansion. In Meta: Translators's Journal. Audiovisual Translation. Vol. 49, 1. 1-11.

Gaudin, A. (2015). Pour un cinéma géopolitique: Los muertos de Lisandro Alonso. In L'écran poétique. Condé-sur-Noireau: Editions Charles Corlet. 34-43.

Genevray, J. (2014). A la manière des grands réalisateurs. Paris: MA éditions. 342 p.

Golynko-Volfson, D.Yu. (2012). Poeticheskij film: postanovka problemy i materialy dl'a ekspertizy [Poetic film: Articulation of the issue and materials for expert review], In Translit, 9. Available at: http://litbook.ru/article/261/ (accessed 29.09.2016)

Cornu, J.-F. (2014). Le doublage et le sous-titrage. Histoire et esthétique. Rennes: Presses universitaires de Rennes. 440 p.

Gorshkova, V.E. (2015). Estetika audiovizual'nogo perevoda Zhana-Fransua Kornju v paradigme sistemnoj transdisciplinarnosti [Aesthetics of Audiovisual Translation by Jean-François Cornu within the Paradigm of Systemic Transdisciplinarity]. In Vestnik Moskovskogo Universiteta. Seria 22. Teorija perevoda [Moscow State University Bulletin. Series 22: Theory of Translation], 3. 22-37.

Gorshkova, V.E. (2016). Khudojestvennij vs dokumental'nij kinodialog: zhanrovaja spetsifika perevoda [Fiction film dialogue vs documentary film dialogue: genre peculiarities of translation]. In Vestnik Rossijskogo universiteta druzhbi narodov. Seria: Lingvistika [Peoples' Friendship University of Russia Journal. Series of Linguistics], Vol. 3, 2. 242-258.

Kergourlay, G. (2015). Poésie numérique et cinéma. In L'écran poétique. Condé-sur-Noireau: Editions Charles Corlet. 60-65.

Konyves, T. (2015). From Filmpoems to Videopoems: The Transformation of Poetry in the Age of the Image. In Program and Abstracts: Poetry/Translation/Film (PoeTransFi). Montpellier: EMMAUniversité Paul-Valéry. 10-11.

Nelyubin, L.L. (2003). Tolkovij perevodovedcheskij slovar' [Explanatory Dictionary of Translation Studies]. Moscow, Flinta: Nauka, 320 p. 
Panh, R. (2015). "Le reel n'existe pas: il y a toujours une mise en scène”. In Documentaire et fiction. Allers et retours. Paris: Les Impressions Nouvelles. 161-183.

Pasolini, P.P. (1985). Poeticheskoje kino [The Cinema of Poetry]. In Strojenije filma. Nekotorije problemi analiza proizvedenij ekrana [Film structure. Some problems of film analysis]; red. K. Razlogov. M.: Raduga. 44-65.

Poirson-Dechonne, M. (2015). Préambule. L'écran de cinéma, un nouveau support pour la poésie? In L'écran poétique. Condé-sur-Noireau: Editions Charles Corlet. 11-14.

Ramière, N. (2004). Comment le sous-titrage et le doublage peuvent modifier la perception d'un film. Analyse contrastive des versions sous-titrée et doublée en français du film d'Elia Kazan 'A Streetcar Naimed Desire' (1951). In Meta: Translators's Journal. Audiovisual Translation. Vol. 49, 1. 102-114. Available at: http://id.erudit.org/iderudit/009026ar (accessed 20.09.2016)

Şerban, A. (2008). Les aspects linguistiques du sous-titrage. In La traduction audiovisuelle. Approche interdisciplinaire du sous-titrage. Bruxelles: De Boeck. 85-99.

\title{
Поэтика аудиовизуального перевода: «Сибирский цирюльник» на французском экране
}

\author{
B.E. Горшкова \\ Иркутский государственный университет \\ Россия, 664025, Иркутск, ул. Ленина, 8
}

\begin{abstract}
Комплексное рассмотрение поэтики в литературоведческом, кинематографическом и переводческом аспекте позволяет автору статьи вывести понятие поэтики аудиовизуального перевода. Постулируется необходимость учёта при переводе субъективного поэтического вйдения режиссёра, обусловливающего жанр поэтического кино в терминах П.П. Пазолини и Ж. Женевре. Рассуждения автора подкреплены ярким иллюстративным материалом из фильма Н. Михалкова «Сибирский цирюльник».
\end{abstract}

Ключевые слова: поэтика, поэтическое кино, аудиовизуальный перевод.

Научная специальность: 10.02.20 - сравнительно-историческое, типологическое и сопоставительное языкознание. 